NBER WORKING PAPER SERIES

\title{
INDIAN EQUITY MARKETS: MEASURES OF FUNDAMENTAL VALUE
}

\author{
Rajnish Mehra \\ Working Paper 16061 \\ http://www.nber.org/papers/w16061

\section{NATIONAL BUREAU OF ECONOMIC RESEARCH 1050 Massachusetts Avenue Cambridge, MA 02138} \\ June 2010
}

Prepared for the India Policy Forum. I thank Surjit Bhalla, Barry Bosworth, Ajay Shay and the participants of the India Policy Forum for their helpful comments; Ellen McGrattan, Edward Prescott and especially John Donaldson for many helpful discussions and Viral Shah for his excellent research assistance. The usual caveat applies. The views expressed herein are those of the author and do not necessarily reflect the views of the National Bureau of Economic Research.

NBER working papers are circulated for discussion and comment purposes. They have not been peerreviewed or been subject to the review by the NBER Board of Directors that accompanies official NBER publications.

(C) 2010 by Rajnish Mehra. All rights reserved. Short sections of text, not to exceed two paragraphs, may be quoted without explicit permission provided that full credit, including $\odot$ notice, is given to the source. 
Indian Equity Markets: Measures of Fundamental Value

Rajnish Mehra

NBER Working Paper No. 16061

June 2010

JEL No. E0,E13,E21,G0,G1,G12

\begin{abstract}
$\underline{\text { ABSTRACT }}$
In this paper, we take a critical look at the relationship between the value of capital stock in the Indian corporate sector and the valuation of claims to this capital stock in capital markets. We address the question of whether Indian equity valuations over the period 1991- 2008 are consistent with three key market fundamentals: corporate capital stock, after tax corporate cash flows and net corporate debt. Our analysis extends the neo-classical growth model to include intangible capital and key features of the tax code and uses national account statistics to estimate the equilibrium value of corporate equity relative to GDP. Our framework can provide policy makers with a benchmark to identify deviations in equity markets relative to those implied by economic fundamentals. In addition, it facilitates a quantitative assessment of policy changes such as, for example, the effect of changes in dividend taxation on stock prices. We caution the reader that although our framework is well suited to examining secular movements in the value of equity relative to GDP, it is not suitable to address high frequency price movements in the stock market. In fact, we know of no framework that can satisfactorily account for these movements in terms of the underlying fundamentals. High frequency volatility remains a puzzle. Based on our analysis, we conclude that in a large measure, Indian equity markets were fairly priced over the 1991-2008 period.
\end{abstract}

Rajnish Mehra

Department of Economics

University of California

Santa Barbara, CA 93106

and NBER

mehra@econ.ucsb.edu 


\section{Summary}

In this paper, we take a critical look at the relationship between the value of capital stock in the Indian corporate sector and the valuation of claims to this capital stock in capital markets. We address the question of whether Indian equity valuations over the period 1991- 2008 are consistent with three key market fundamentals: corporate capital stock, after tax corporate cash flows and net corporate debt. Our analysis extends the neo-classical growth model to include intangible capital and key features of the tax code. Unlike the standard partial equilibrium valuation framework, our paradigm allows us to explicitly capture the interaction between the growth in per capita consumption and interest rates, which fundamentally changes the role of the present value of growth opportunities in explaining a run up in equity prices. In a general equilibrium model with production, growth per se will not increase the value of equity relative to GDP. A second advantage is that it allows us to examine dividends and stock prices relative to GDP. These series are themselves non-stationary; however, they appear to be co-integrated with GDP. Examining these aggregate values relative to GDP induces stationarity and is a natural normalization that eliminates the need for adjustments due to inflation. Finally, it provides a framework to evaluate policy changes such as the effect of changes in dividend taxation on stock prices.

We specify the price per share of corporate equity as a function of tax rates and capital stocks and define an equilibrium relationship between the market value of equity and the reproduction value of the tangible and intangible capital, to which the equity represents claim. Next, we estimate the intangible capital stock in India and use this to develop estimates for equilibrium equity valuations. The challenge in estimating equity valuation is that we do not have 
readily available measures for the intangible capital stock in India. We estimate this stock of intangible capital for the two periods 1991-2004 and 2005-2008 using three different techniques. We have chosen these periods to capture a structural break in data: Indian equity valuations as a fraction of GDP were fairly constant over the period 1991-2004, rising sharply starting in 2005 .

We begin by using the methodology in McGrattan and Prescott (2005). Next, we use the measures in Corrado et al (2005) for the U.S economy to infer the corresponding capital stock levels in India. We conclude by constructing our own measures using actual investment data for India.

The McGrattan and Prescott approach uses data on corporate profits and assumes that after-tax returns to both tangible and intangible capital are equal. This facilitates an estimate of the stock of intangible capital. An advantage of this approach is that it does not require any knowledge of the rate of depreciation of intangible capital. Corrado et al (2006) provide estimates for the value of various forms of intangible capital in the U.S based on investment data. Since we did not have access to a data set for India that details the investment in intangible capital for all the categories considered in Corrado et al, we tease out information from their data to estimate the stock of intangible capital in India. Working with investment data for innovative property and brand equity and assuming that depreciation rates for tangible capital are similar in the U.S and India, we use the transformation rates for flows into stocks implied by their data for our estimation.

Further, using India specific investment data on Innovative Property, which includes R\&D and Technical knowledge and Brand Equity, we construct direct measures of the stock of these types of intangible capital and compare them with our earlier estimates derived using the Corrado et al (2006) data. While these estimates for the intangible capital stock are similar to each other, they are lower than the estimates using the McGrattan -Prescott methodology. 
One reason is the high depreciation rates used by Corrado et al (2006); another possibility is that organizational capital, in particular investment in learning-bydoing, is probably underestimated in their analysis.

We relate the price earnings ratio and Tobin's q, defined as the ratio of the market value of equity and net debt to tangible capital at replacement cost, and a popular ratio to estimate over and undervaluation of equity, to the quantities identified in our model formulation. In the absence of intangible capital, the equilibrium value of $q$ is 1 . Unfortunately, in an economy with changing tax rates and significant intangible capital the usefulness of $q_{t}$ is limited. In a setting with corporate taxes, distribution taxes (i.e. taxes on dividends and capital gains) and subsidies to investment (e.g. investment tax credits) not only is its equilibrium value not 1, but it is significantly impacted by changes in the tax code, in particular, with changes in the tax rates on corporate distributions which have varied considerably in India from year to year. Thus $q_{t}$ may differ from 1 either because of over or undervaluation in capital markets or simply as a result of changes in the tax rates - the ratio per se does not distinguish between the two.

A measure closely related to $\mathrm{q}$ is the price earnings $(\mathrm{P} / \mathrm{E})$ ratio - the ratio of the stock price to earnings per share or at the aggregate level the value of equity normalized by after tax corporate profits. We parse its mechanics and usefulness for Indian equity markets and conclude that both $\mathrm{q}$ and $\mathrm{P} / \mathrm{E}$ ratios, which implicitly abstract from tax rates and intangible capital, offer inadequate measures of under and over valuation of capital markets. In particular, for economies with sizable secular growth in intangible capital, as has been observed in India over the last 15-20 years, these metrics offer limited analytical utility.

Our analysis suggests that an optimistic estimate of fundamental value of the current Indian equity market is about 1.2, considerably lower than the 1.6 value observed in 2008. One effect that we have not accounted for is demand from foreign institutional investors. If the effect of this is to change the marginal 
investor, the relevant marginal rate of substitution will change, and with it valuations as well. These are issues that we plan to pursue in subsequent research. 


\section{Introduction:}

Indian equity markets had their inception in the early 1830s with trading in shares of banks and cotton mills ${ }^{1}$. The first organized exchange -- the Native Share and Stock Brokers' Association (forerunner of the Bombay Stock Exchange) -- was established in 1887, making it the oldest in Asia². By independence, in 1947, the number of exchanges had increased to seven and the market capitalization of listed companies was approximately Rs. 10 billion (0.11 $\left.\mathrm{GDP}^{3}\right)$. In the subsequent forty odd years, however, equity markets languished, and by 1990, although market capitalization of equity had increased to Rs. 697.16 billion in nominal terms, its relative value was only 0.135 GDP (Figure1).

Following economic reforms instituted after the balance of payments crisis in 1991, equity valuations increased sharply. By 1993, equity values had risen to about 0.4 GDP and remained at approximately that level for almost 12 years ${ }^{4}$. Beginning in 2005, Indian equities went through a period of exponential growth culminating in a peak value of Rs.67.46 trillion (1.56 GDP) in early 2008. This propelled India into the 'trillion-dollar club' and the Bombay Stock Exchange (BSE) became a 'top ten' exchange in terms of market capitalization. However, by the end of 2008, Indian equity valuations had dropped to around 0.83 GDP and by March 2009 even further to 0.7 GDP. India had exited the 'trillion-dollar club ${ }^{5}$.

\footnotetext{
${ }^{1}$ The market experienced its first crash in 1865 . The run up in stock prices prior to the crash was a consequence of the increased demand for Indian cotton precipitated by the disruption of cotton supplies from America due to the American Civil War.

${ }^{2}$ Bajpai (2004).

${ }^{3}$ In Section 2, we argue that in the case of India, a more accurate representation is obtained if we normalize valuations with respect to non-agricultural GDP (NAGDP) rather than GDP.

${ }^{4}$ Since real GDP growth over this period was $8 \%$ a year, the near constancy of the market value of equity/ GDP ratio implies that equity markets also appreciated at this rate, doubling every 9 years.

${ }^{5}$ By early June 2009, the market capitalization of Indian equities was again USD 1 trillion.
} 


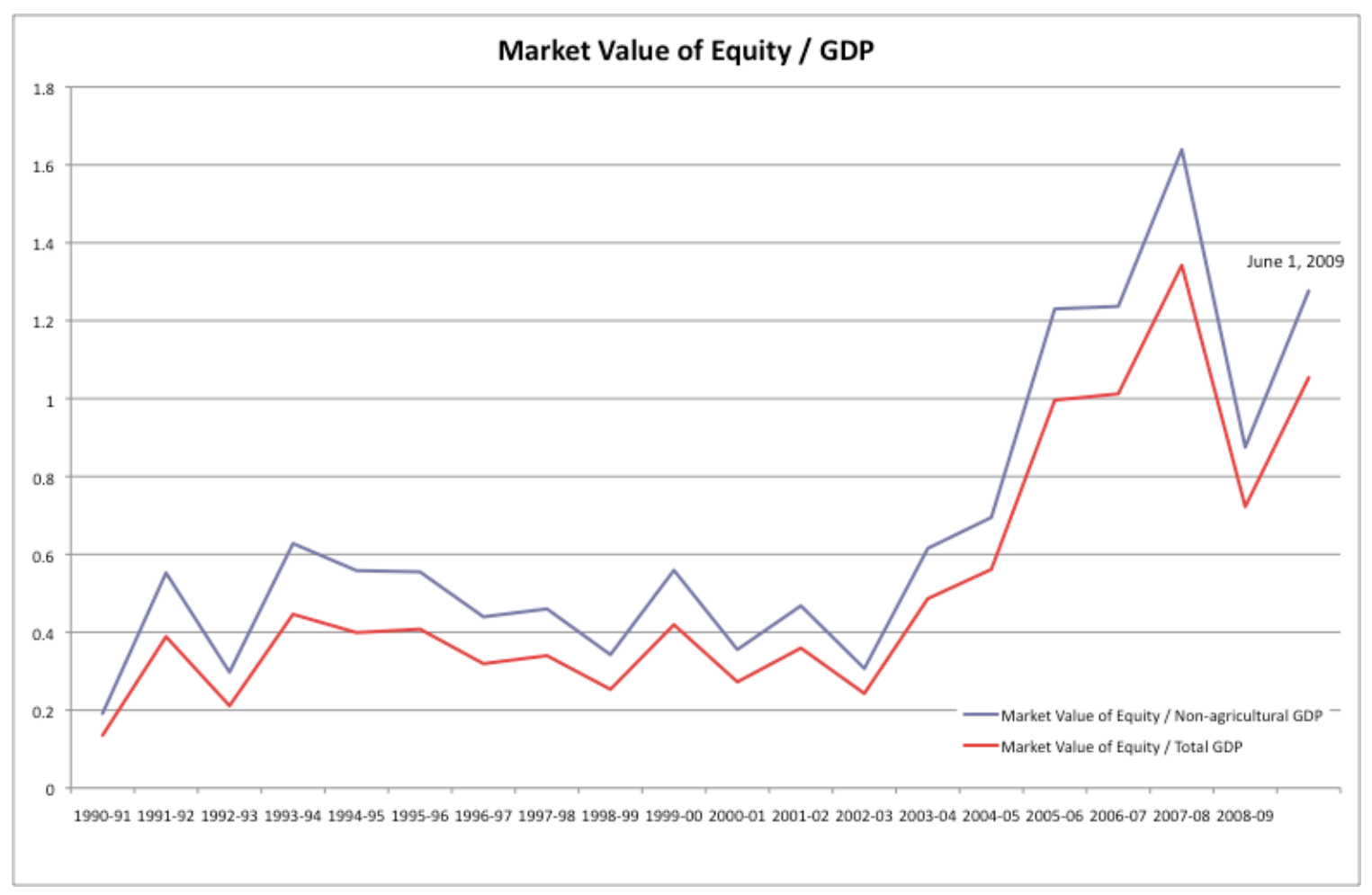

Source: Market Value of Equity is for the CMIE COSPI set. GDP data is from National Accounts

Figure 1: The top line plots market value of equity as a multiple of non -agricultural GDP. The bottom line plots market value of equity as a multiple of GDP.

These large swings in equity valuation were not limited to India alone. Starting in the mid 90s, there was a considerable increase in U.S equity prices to an extent that prompted then Federal Reserve Chairman, Alan Greenspan, to characterize the run up as "irrational exuberance".

These dramatic changes in valuation suggest the possibility that at least part of this fluctuation was a response to changes in determinants other than the underlying factors of production or technology. Largely as a consequence of this run up, the possibility of departures of stock price valuations from " equilibrium or fundamental values " has gained center stage in academic research. In the 70s and $80 \mathrm{~s}$, the halcyon days of the efficient market hypothesis, the prevailing paradigm was that stock prices were an unbiased estimate of some underlying 
"fundamental" or "intrinsic" value. If at any point in time, the observed price of an asset is a fair indicator of it's intrinsic worth, over and undervaluation become meaningless constructs. What these underlying fundamental values actually were, was left unspecified and for good reason: there was no explicit theoretical framework linking the value of the capital stock to prices of claims to this capital stock - debt and equity - prevailing in the capital markets ${ }^{6}$. The first models ${ }^{7}$ to make these connections appeared in the early 1980s; however, they were ill suited to the task of quantifying over and undervaluation in capital markets, as they abstracted from two key ingredients: intangible capital ${ }^{8}$ and taxes. The equilibrium conditions in these models required that the value of the claims to the capital stock be equal to the tangible capital of the firm or, equivalently, that their ratio (Tobin's q) be 1. This was not empirically observed and together with the models' inability to address the equity premium puzzle, cast doubt on their usefulness as a measurement tool and provide a benchmark for capital markets valuations. In 2005, McGrattan and Prescott (2005) extended the standard growth model to incorporate both intangible capital and taxes. In doing so, they were able to account for the secular movements in the value of U.S equity relative to GDP. The extended standard growth model can serve as a reference for over and undervaluation in capital markets. Their analysis highlights the importance of the role that intangible capital and distribution taxes play in explaining variations in equity valuation.

In this paper, we take a critical look at the relationship between the value of the capital stock in the Indian corporate sector and the valuation of claims to

\footnotetext{
6 See Bosworth (1975) for an early empirical study linking stock prices to economic activity.

${ }^{7}$ Prescott and Mehra (1980), Brock (1979 and 1982), Donaldson and Mehra (1984) and Cox et al (1985).

${ }^{8}$ Unlike tangible capital, intangible capital cannot be measured directly: it includes brand names, scientific and technical knowledge, patents, and organizational capital. As an example, consider the difference between owning a thousand trucks (tangible capital) and running a trucking company that owns a thousand trucks. The difference in the value of the trucking business and the thousand trucks is a measure of intangible capital. I thank Ajay Shah for this example.
} 
this capital stock in capital markets. We address the question of whether Indian equity valuations over the period 1991- 2008 are consistent with three key market fundamentals: corporate capital stock, after tax corporate cash flows and net corporate debt. Our analysis extends the neo-classical growth model ${ }^{9}$ to include intangible capital and key features of the tax code. This paradigm has several advantages. Unlike the standard partial equilibrium valuation framework ${ }^{10}$, it allows us to capture explicitly the interaction between the growth in per capita consumption and interest rates. This interaction fundamentally changes the role of the present value of growth opportunities (PVGO) in explaining a run up in equity prices. In a general equilibrium model with production, growth per se will not increase the value of equity relative to $\mathrm{GDP}^{11}$. A second advantage is that it allows us to examine dividends and stock prices relative to GDP. These series are themselves nonstationary; however, they appear to be co-integrated with GDP. Examining these aggregate values relative to GDP induces stationarity and is a natural normalization in this theoretical setting. It also eliminates the need for adjustments due to inflation. Finally, it provides a framework to evaluate policy changes such as the effect of changes in dividend taxation on stock prices.

Although our framework is well suited to examining secular movements in the value of equity relative to GDP, it is not a suitable framework to address high frequency price movements in the stock market. In fact, we know of no framework that can satisfactorily account for these movements in terms of the underlying fundamentals. High frequency volatility remains a puzzle ${ }^{12}$.

\footnotetext{
${ }^{9}$ This model and its stochastic variants are a central construct in contemporary finance, public finance and business cycle theory. It is the basis for much of our economic intuition and has been used extensively by, among others, Abel et al. (1989), Auerbach and Kotlikoff (1987), Barro and Becker (1989), Brock (1979), Cox, Ingersoll and Ross (1985), Donaldson and Mehra (1984), Lucas (1988), Kydland and Prescott (1982), McGrattan and Prescott (2005) and Merton (1971).

10 See for example Fama and Miller (1972).

11 For an elaboration see Kiley (2004)

12 The "volatility puzzle" has its origins in the important early work of Shiller (1981) and LeRoy and Porter (1981), which found evidence of excessive volatility of stock prices relative to the
} 
This paper is organized as follows: in Section 2, we derive an equilibrium relationship between the value of equity and net debt and the value of tangible and intangible corporate capital. Corporate tax rates and tax rates on distributions to equity and debt holders figure prominently in these relationships. We calibrate the economy in Section 3. In Section 4, using firm level investment data in intangible capital from CMIE, we estimate the intangible capital stock. In Section 5, we use the relationships developed in Section 2 to obtain estimates of Indian equity valuation. In doing so, we are able to provide a theoretically grounded sense of market efficiency. In section 6 , we take a critical look at two popular valuation metrics, Tobin's q and price earnings $(\mathrm{P} / \mathrm{E})$ ratio and examine their appropriateness in light of the theory developed in section 2. Section 7 concludes the paper.

\section{An Equilibrium Valuation Model}

\subsection{Overview}

We extend standard growth theory by incorporating intangible capital and use it to value the Indian equity market ${ }^{13}$. Our model is similar to that analysed by McGrattan and Prescott (2005) and our exposition closely follows their paper. One implication of the model is that the value of corporate equity and debt should be equal to the value of the productive assets in the corporate sector. The challenge is to find the value of these assets in terms of the consumption good. The table below classifies the components of corporate capital stock and the

underlying dividend/earnings process. These studies use a constant interest rate, an assumption subsequently relaxed by Grossman and Shiller (1981) who addressed the issue of varying interest rates. They concluded that although this reduced the excess volatility, Shiller's conclusion could not be overturned for reasonable values of the coefficient of relative risk aversion.

${ }^{13}$ The importance of intangible capital, both for growth accounting and corporate valuation has received considerable attention. See papers by Bond and Cummins (2000), Corrado et al (2005), McGrattan and Prescott (2001 and 2005) and Hall (2000 and 2001) and the volume by Corrado et al (2005). Bond and Cummins stress the importance of brand names for valuing corporations like Coca Cola. Hall stresses the importance of "e-capital," for valuing high tech companies. 
claims to this capital stock. In the model, in the absence of all taxes, the equilibrium relationship specifying the price of equity $\left(p_{t}\right)$ and net debt $\left(b_{t}\right)$ as a function of corporate capital stocks is

$$
p_{t}+b_{t}=k_{m, t+1}+k_{u, t+1}
$$

where $k_{m, t}$ and $k_{u, t}$ are, respectively. the tangible (measured) and intangible (unmeasured) capital stock.

\section{Table 1}

\begin{tabular}{c|c} 
Corporate Capital Stock & Claims to Corporate Capital \\
\hline Tangible Capital $k_{m}$ & Equity $p$ \\
Fixed corporate capital & Net Debt $b$ \\
Inventory stocks & \\
Corporate land & \\
Intangible Capital $k_{u}$ & \\
Brand names \\
Patents
\end{tabular}

In Table 1, capital stocks are measured or estimated in terms of their reproduction cost, while the values of debt and equity are market values. The empirical counterpart of tangible corporate capital is the sum of fixed corporate capital stocks, inventory stocks and the value of corporate-owned land. Intangible capital includes brand names, patents, and forms of organizational capital. Intangible capital is not measured directly and as Indian National Accounts do not report its value, it must be estimated. One approach to estimate the value of intangible corporate assets is to attribute the return on capital used in the corporate sector to both tangible and intangible capital and assume that the 
after-tax returns to both types of capital are equal. We detail this and other estimation procedures in Section 4.

\subsection{Model Formulation}

To derive an equilibrium relationship between the value of productive capital and the market value of corporations, we initially assume that firms are all equity financed. ${ }^{14}$ Following McGrattan and Prescott (2005) we also abstract from uncertainty, as it is an unimportant feature for our results. We take note of the findings in Bosworth et al (2007) who point out the heterogeneity in the contribution of different sectors of the economy to India's growth rate. The large agriculture sector in India has a very low capital labour ratio and little of its capital is publicly traded. Since the focus of this paper is on capital valuation in securities markets, we exclude the agriculture sector from our analysis and only model the non-agricultural sector ${ }^{15}$. One implication of our approach is that when we normalize capital valuations relative to GDP, we will use only the contribution to GDP of the non-agricultural sector (NAGDP). Within the nonagricultural sector, we introduce a dichotomy between workers and shareholders ${ }^{16}$. This distinction is particularly germane to the Indian context as workers generally do not hold equity either directly or indirectly and hence may have different future marginal rates of substitution compared to stockholders as their consumption growth rates may differ. In valuing equity, we use the marginal rates of substitution of the stockholders.

In light of the discussion above, we model the economy as one with two agents, workers and shareholders who take prices as given. There is also one firm that maximizes its value taking prices as given. These single entities, the workers,

\footnotetext{
14 We relax this assumption when we discuss our results.

15 Equivalently, the reader may view the Indian economy as being split into two disjoint sectors, one of them being the agriculture sector. For a balanced growth model with integrated agricultural, services and manufacturing sectors see Kongsamut et al (2001). Their model features a rapidly declining agricultural sector which is beginning to be observed in India. 16 See Danthine et al (2008) and Mankiw and Zeldes (1991)
} 
shareholders and the firm are respectively 'stand in' representatives of a continuum of such agents distributed on the unit interval. We abstract from population growth in the analysis below, as it does not change the valuation relation we derive but simplifies the notation and allows us to use per capita and aggregate quantities interchangeably. We will re-introduce it when we calibrate the $\operatorname{model}^{17}$.

\section{The Worker}

The representative worker supplies labour $\left(n_{t}^{w}\right)$ inelastically and consumes his aggregate wages $\left(w_{t} n_{t}^{w}\right)$. The workers does not trade securities and thus does not borrow or save. He maximizes the present value of his present and future utility of consumption $\left(c_{t}^{w}\right)$ :

$$
\max _{\left\{c_{t}^{w}, n_{t}\right\}} \sum_{t=0}^{\infty} \beta^{t} v\left(c_{t}^{w}\right)
$$

subject to

$$
c_{t}^{w} \leq w_{t} n_{t}^{w} \text { and } n_{t}^{w} \leq 1
$$

The solution to this problem is $c_{t}^{w}=w_{t}$ and $n_{t}^{w}=1$ since there is no presumed disutility of work.

\section{The Shareholder}

The shareholder owns all the securities $\left(z_{t}\right)$ in the economy and consumes the aggregate dividends $\left(d_{t}\right)$. There is one perfectly divisible equity share outstanding. Shareholders do not supply any labour. The representative

17 In the absence intangible capital, tax rates and subsidies our model reduces to the standard decentralized growth model. Thus setting these quantities to zero in section 5 gives us the equilibrium valuation implied by the standard model. 
shareholder also maximizes the present value of his utility of consumption $\left(c_{t}^{s}\right)$ :

$$
\max _{\left\{c_{t}^{s}, z_{t}\right\}} \sum_{t=0}^{\infty} \beta^{t} u\left(c_{t}^{s}\right)
$$

subject to

$$
c_{t}^{s}+p_{t} z_{t+1} \leq\left(p_{t}+d_{t}\left(1-\tau_{d}\right)\right) z_{t}+\pi_{t} \text { and } 0 \leq z_{t} \leq 1
$$

where $p_{t}$ is the price per share, $\tau_{d}$ is the tax on dividends or share buy backs and $\pi_{t}$ is the value of taxes rebated back to the shareholder in lump sum form. The budget of shareholder specifies that his consumption plus the value of shares that he carries over to the next period be less than or equal to the value of the portfolio at the beginning of the period plus government transfers.

\section{The Firm}

The firm uses labour and capital (tangible and intangible) to produce output $y_{t}$. It is characterized by a constant returns to scale production function $y_{t}=f\left(k_{m, t}, k_{u, t}, \lambda_{t} n_{t}^{f}\right)$ with productivity growth rate $\gamma$ so that

$$
\lambda_{t+1}=(1+\gamma) \lambda_{t}
$$

Firms act competitively to maximize shareholder value using the marginal rate of substitution provided by the representative shareholder. It solves:

$$
\max _{\left\{x_{u, t}, x_{m_{n}, t}, n_{t}^{f}\right\}} p_{t}+d_{t}=\max _{\left\{x_{u, t}, x_{m, t}, n_{t}^{f}\right\}} \sum_{j=0}^{\infty} \frac{\beta^{j} u_{1}\left(c_{t+j}^{s}\right)}{u_{1}\left(c_{t}^{s}\right)} d_{t+j}
$$

subject to

$$
\begin{gathered}
d_{t}=f\left(k_{m, t}, k_{u, t}, \lambda_{t} n_{t}^{f}\right)-w_{t} n_{t}^{f}-x_{m, t}-x_{u, t}-\text { taxes }+ \text { subsidies } \\
\left.k_{u, t+1}=\left(1-\delta_{u}\right) k_{u, t}+x_{u, t}\right) \\
\left.k_{m, t+1}=\left(1-\delta_{m}\right) k_{m, t}+x_{m, t}\right)
\end{gathered}
$$




$$
\begin{gathered}
\text { taxes }=\tau_{c}\left(f\left(k_{m, t}, k_{u, t}, \lambda_{t} n_{t}^{f}\right)-w_{t} n_{t}^{f}-k_{m, t} \delta_{m}-x_{u, t}\right) \\
\text { subsidies }=\tau_{s} x_{m, t}
\end{gathered}
$$

where $\tau_{s}$ is the subsidy for investment in tangible capital (such as an investment tax credit), $\tau_{c}$ is the corporate tax rate, $x_{m, t}$ and $x_{u, t}$ represent tangible and intangible investment at time $\mathrm{t}$ and $\delta_{u}$ and $\delta_{m}$ are the depreciation rates for these capital stocks respectively. $n_{t}^{f}$ is the per capita labour demanded by the firm.

In (P3) the first constraint defines the dividend as output net of wages, investments, taxes and subsidies. The second and third are the standard laws of motion of capital stock, both tangible and intangible. The constraint on taxes recognizes that wages, intangible investment and depreciation of tangible capital are tax-deductible expenses. The final constraint defines the subsidy to capital investment.

The rate of return, defined by the marginal rate of substitution of the stockholders in this economy, is:

$$
1+r_{t+1}=\frac{u_{1}\left(c_{t}^{s}\right)}{\beta u_{1}\left(c_{t+1}^{s}\right)}
$$

Equilibrium in this economy is defined by per capita sequences of consumption $\left(c_{t}^{s}, c_{t}^{w}\right)$, investment $\left(x_{m, t}, x_{u, t}\right)$ and labour $\left(n_{t}^{w}, n_{t}^{f}\right)$ that simultaneously satisfy:

a) the necessary and sufficient first order conditions for the firm's problem

$$
\begin{aligned}
& \left(1+r_{t+1}\right)=\frac{\left(1-\tau_{c}\right)\left[f_{1}\left(k_{m, t}, k_{u, t}, \lambda_{t} n_{t}^{f}\right)-\delta_{m}\right]}{\left(1-\tau_{s}\right)}+1 \\
& \left(1+r_{t+1}\right)=f_{2}\left(k_{m, t}, k_{u, t}, \lambda_{t} n_{t}^{f}\right)-\delta_{u}+1 \\
& w_{t}=f_{3}\left(k_{m, t}, k_{u, t}, \lambda_{t} n_{t}^{f}\right)
\end{aligned}
$$


b) the necessary and sufficient first order conditions for the shareholders problem:

$$
u_{1}\left(c_{t}^{s}\right) p_{t}=\beta u_{1}\left(c_{t+1}^{s}\right)\left(p_{t+1}+d_{t+1}\left(1-\tau_{d}\right)\right)
$$

c) market clearing conditions:

$$
\begin{aligned}
& z_{t}=1 \\
& n_{t}^{w}=n_{t}^{f}=1 \\
& c_{t}^{w}+c_{t}^{s}=f\left(k_{m, t}, k_{u, t}, \lambda_{t} n_{t}^{f}\right)-x_{m, t}-x_{u, t}+\pi_{t} \\
& \text { where } \pi_{t}=\text { taxes }- \text { subsidies }
\end{aligned}
$$

Equations 2 and 3 equate the marginal return on tangible and intangible capital to the marginal rate of substitution of the shareholders while equation 4 defines the wage rate. It follows from (2), (3) and (5) that the equilibrium relation specifying the price per share of corporate equity as a function of tax rates and capital stocks is

$$
p_{t}=\left(1-\tau_{d}\right)\left[\left(1-\tau_{s}\right) k_{m, t+1}+\left(1-\tau_{c}\right) k_{u, t+1}\right]
$$

which is also the total equity value.

Equation 6 represents the equilibrium, full information, rational valuation relationship between the market value of equity and the reproduction value of the tangible and intangible capital, to which the equity represents claim. In the next section, we estimate the intangible capital stock in India and then use (6) in Section 4 to develop estimates for equilibrium equity valuations. In Section 5, we 
will use (6) to evaluate the theoretical appropriateness of other commonly used valuation techniques.

\section{Calibration}

In the analysis below, we have split the time period 1991-2008 into two sub periods 1991-2004 and 2005-2008 since 2005 marked the beginning of a substantial run up in the equity markets $^{18}$.

Table 2

\begin{tabular}{|c|c|c|}
\hline Parameter & 1991-2004 & 2005-2008 \\
\hline Population Growth Rate of shareholders $(\zeta)$ & 0.015 & 0.015 \\
\hline Growth Rate of Technology $(\gamma)$ & 0.052 & 0.088 \\
\hline Growth of Real NAGDP $(\gamma+\eta)$ & 0.067 & 0.103 \\
\hline Growth of Real Consumption $(\nu)$ & 0040 & $0 \Omega 40$ \\
\hline Estimated over the period 1991-2008 & & \\
\hline Discount Factor $(\beta)$ & 0.96 & 0.96 \\
\hline Elasticity of Intertemporal Substitution $(\eta)$ & 0.33 & 0.33 \\
\hline Real Interest Rate Implied by Model Parameters $\left(r_{t}\right)$ & 0.141 & 0.141 \\
\hline Effective Corporate Tax Rate on PBDIT $\left(\tau_{c}\right)$ & 0.098 & 0.159 \\
\hline Distribution Tax Rate $\left(\tau_{d}\right)$ & 0.10 & 0.125 \\
\hline Investment Tax Credit $\left(\tau_{s}\right)$ & 0 & 0 \\
\hline Growth of Real NAGDP $(\gamma+\zeta)$ & 0.067 & 0.103 \\
\hline
\end{tabular}

18 The theory that we have developed is meant to deal with low frequency movements in the underlying factors of production and technology and averaging over the 2005-08 period assumes that this trend will continue. 


\begin{tabular}{lcc}
\hline Profits Before Interest and Taxes $(C P)$ & 0.156 & 0.192 \\
Corporate Tangible Capital $\left(k_{m}\right)$ & 0.783 & 0.939 \\
\hline
\end{tabular}

\section{Unless otherwise stated all data is from the CMIE Business Beacon}

The parameters that need to be "calibrated" are those related to the shareholders $\{\beta, \zeta, u()$.$\} ; the firm \left\{\delta_{m}, \gamma, x_{m}, k_{m}\right.$,after tax cash flows $\left.(C F)\right\}$ and the policy parameters $\left\{\tau_{c}, \tau_{d}, \tau_{s}\right\}$. Some of these parameters are well documented in the literature; others are not. Table 2 details the parameter values that we use for the Indian economy. We explain below the motivation for choosing these values.

We choose $\zeta$ to match the population growth of the shareholders. The population growth rate for this group we believe is lower than the general population growth rate $(1.7 \%)$ or for the working age population $(2 \%)$. We calibrate the growth rate of productivity $\gamma$ by matching $\gamma+\zeta$ to the average real growth rate of output from the non-agricultural sector (NAGDP). As discussed earlier, we use this growth rate rather than the growth rate of GDP as agriculture in India uses very little capital, and is likely to have a markedly different aggregate production function than the one that characterizes the non agricultural sector. We choose $\beta=0.96$ as it is a standard value for the discount factor in much of the macroeconomic literature. Out theory requires that the tax $\tau_{c}$, be the effective tax rate faced by the suppliers of capital to the firm. Since interest payments are tax deductible this effective rate is much lower than the marginal corporate tax rate. Each year we estimate the effective corporate tax rate from data on corporate taxes paid and profits before interest and taxes and then take the appropriate averages: $\tau_{c}=$ actual corporate taxes paid/ profits before interest and taxes. We calibrate $\tau_{d}$ to the marginal tax rate. We note that the tax rate on dividends has changed frequently and we will revisit this issue 
when we discuss our results. We fix $\tau_{s}=0$, as there is no investment tax credit in India. To calibrate the interest rate, we use CRRA preferences with elasticity of intertemporal substitution $\eta=1 / 3$ and calculate the marginal rate of substitution of the shareholders. We use the average growth rate of per capita of consumption over the entire period 1991-2008 for this calibration.

$$
r \approx \frac{1}{\beta}+\nu / \zeta-1
$$

It is well known that the real interest rate implied by the growth model is counterfactually high in economies with high growth rates and this is probably the case in our model ${ }^{19}$.

We use data on net private stock of corporations to estimate $k_{m}$. It is expressed as a fraction of the non-agricultural output. We estimate the after tax cash flow to debt and equity holders (net of depreciation of tangible capital and investment in intangible capital), $C F$ by making appropriate adjustments corporate profits before depreciation, interest and taxes. It is also expressed relative to NAGDP. We assume that the economic depreciation rate is equal to the accounting depreciation rate, which averages $5 \%$ when measured relative to $k_{m}$. The depreciation rates allowed by the Indian tax code are far more generous, however, net of inflation they average to around 5\%, which is what is reported in the Indian National Accounts.

\section{Methodology for Estimating Intangible Capital Stock}

The challenge in using the relationship developed in equation (6) for equity valuation is that we do not have readily available measures for the

\footnotetext{
${ }^{19}$ High growth rates that characterize developing economies are unlikely to continue indefinitely and hence are not likely to be observed in steady state. For example, a growth rate of $6 \%$ implies a doubling in standard of living ever twelve years compared to a doubling every thirty six years in the U.S.
} 
intangible capital stock in India. We estimate the intangible capital stock using three different techniques. We begin by using the methodology in McGrattan and Prescott (2005). Next, we use the measures in Corrado et al (2005) for the U.S economy to infer the corresponding capital stock levels in India. We conclude by constructing our own measures using actual investment data for India.

\subsection{The McGrattan and Prescott Methodology}

McGrattan and Prescott start by using data on corporate profits and assume that after-tax returns to both tangible and intangible capital are equal. This enables them to estimate the stock of intangible capital. An advantage of their approach is that it does not require knowledge of the rate of depreciation of intangible capital.

We illustrate their approach in a world without taxes. The accounting concept that corresponds to the model counterpart of pre tax corporate profits is profits before interest and taxes (PBIT) can be written as

$$
P B I T=y_{t}-w_{t} n_{t}^{f}-x_{u, t}-\delta_{m} k_{m, t}
$$

Using the first order conditions (2) and (3) and the fact that the production function displays constant returns to scale i.e.

$$
f_{1}\left(k_{m, t}, k_{u, t}, \lambda_{t} n_{t}^{f}\right) k_{m, t}+f_{2}\left(k_{m, t}, k_{u, t}, \lambda_{t} n_{t}^{f}\right) k_{u, t}+w_{t} n_{t}^{f}=y_{t}
$$

we can re write (PBIT) as

$$
P B I T=r_{t} k_{m, t}+\left(\delta_{u}+r_{t}\right) k_{u, t}-x_{u, t}
$$

Finally using the fact that on a balanced growth path

$$
\begin{gathered}
x_{u, t}=\left(\gamma+\eta+\delta_{u}\right) k_{u, t} \\
P B I T=r_{t} k_{m, t}+\left(r_{t}-\gamma-\eta\right) k_{u, t}
\end{gathered}
$$


In the presence of taxes this expression is modified to

$$
P B I T=\frac{r_{t}}{1-\tau_{c}} k_{m, t}+\left(r_{t}-\gamma-\eta\right) k_{u, t}
$$

where we remind the reader that $\tau_{c}$ is defined as

$$
\tau_{c}=\frac{\text { corporate taxes paid }}{P B I T}
$$

It is the average tax rate on PBIT not the marginal corporate tax rate.

The intangible capital stock can thus be estimated from equation (7) in terms of the observed parameters of the economy. We note that in deriving (7) we have assumed that the economy is (approximately) on a balanced growth trajectory, a condition that may not have been be true in India in the early 90s.

Using values in Table 2, we can estimate the average value of the intangible capital for the two periods 1991-2004 and 2005-2008. As mentioned earlier, we have chosen these periods to capture a structural break in 2005 . Indian equity valuations as a fraction of GDP were fairly constant over the period 1991-2004, rising sharply starting in 2005. Our estimates are presented in Table 3.

Table 3

Average values measured as a fraction of non-agricultural GDP

\begin{tabular}{lcc}
\hline & $1991-2004$ & $2005-2008$ \\
\hline After Tax Cash Flows & 0.1754 & 0.1991 \\
Estimate of Intangible Capital & 0.447 & 0.883 \\
\hline
\end{tabular}




\subsection{Alternative Estimates of Intangible Capital in India - 1}

Corrado et al (2006) provide estimates for the value of various forms of intangible capital in the U.S based on investment data. The investment data is presented in Table 4 below and the corresponding estimates of intangible capital in Table 5.

\section{Table 4}

Intangible Investment (U.S 2000-2003 annual average)

\begin{tabular}{lcc} 
& Billions of Dollars & Percentage of GDP \\
\multicolumn{1}{c}{ Intangible Investment } & 1226 & $11.19 \%$ \\
Computerized Information & 173 & $1.58 \%$ \\
Innovative Property & 468 & $4.27 \%$ \\
R\&D (Scientific) & 231 & $2.11 \%$ \\
Non-scientific & 237 & $2.16 \%$ \\
Economic Competencies & 586 & $5.35 \%$ \\
Brand equity & 161 & $1.47 \%$ \\
Firm-specific resources & 425 & $3.88 \%$ \\
& From Corrado et al (2006), Table 2
\end{tabular}

\section{Table 5}

Estimate of Intangible Capital Stock (U.S 2003)

Intangible Capital Stock

Computerized Information

Innovative Property

$\mathrm{R} \& \mathrm{D}$ (Scientific)

Non-scientific

Economic Competencies

Brand equity

Firm-specific resources
Billions of Dollars

3636

512

1786

922

864

1338

272

1066
Percentage of GDP

$33.18 \%$

$4.67 \%$

$16.30 \%$

$8.41 \%$

$7.88 \%$

$12.21 \%$

$2.48 \%$

$9.73 \%$

From Corrado et al (2006), Table 3 
Corrado et al (2006) report that for the period 2000-03, the aggregate U.S investment in intangible assets averaged $11.19 \%$ of GDP and estimate that these investment levels translate into a stock of intangible capital valued at $33.18 \%$ of GDP. As Tables A1 and A2 show (see the Appendix), due to differing depreciation rates the rate of transformation of investment flows into capital stock vary considerably.

Unfortunately, we do not have access to a data set for India that details the investment in intangible capital for all the categories considered by Corrado et al (2006). We can, however, tease out information from their data (Tables 4 and 5) to estimate the stock of intangible capital in India. Since, we have investment data for innovative property (both scientific and non scientific) and brand equity (Table 6), if we assume that depreciation rates for tangible capital are similar in the U.S and India, we can use the transformation rates for flows into stocks implied by their data for our estimation. Our capital stock estimates are reported in Table 7 .

\section{Table 6}

Intangible Investment (India 2004-2008 annual average)

Billions of INR Percentage of NAGDP

\section{Intangible Investment}

Computerized Information

Innovative Property

Non-scientific

Firm-specific resources 


\section{Table 7}

\section{India 2008}

Estimate of Intangible Capital Stock using Corrado et al (2006)

$\begin{array}{ll}\text { Intangible Capital Stock } & \text { Billions of INR Percentage of NAGDP }\end{array}$

Computerized Information

$\begin{array}{lcc}\text { Innovative Property } & 1,467 & 4.15 \% \\ \text { R\&D (Scientific) } & 394 & 1.11 \% \\ \text { Non-scientific } & 1,073 & 3.03 \% \\ \text { Economic Competencies } & & \\ \quad \text { Brand equity } & 482 & 1.36 \% \\ \text { Firm-specific resources } & & \end{array}$

\subsection{Alternative Estimates of Intangible Capital in India -2}

Since we have investment data on Innovative Property, which includes R\&D and Technical knowledge and Brand Equity, we can also construct direct measures of the stock of these types of intangible capital and compare them with our earlier estimates derived using the Corrado et al (2006) data. To do so, we use the law of motion for capital stock relative to non - agricultural GDP

$$
\begin{aligned}
& \frac{k_{t+1}}{y_{t+1}}=\left[\frac{k_{t}}{y_{t}}(1-\delta)+\frac{x_{t}}{y_{t}}\right] \frac{1}{(1+\gamma+\eta)} \\
& \frac{k_{0}}{y_{0}}: \text { given }
\end{aligned}
$$

For a given initial capital stock, the future capital stock at any date t can be calculated by recursively using equation (8). We initialize the capital stock to 
zero in 1990 and use a variety of depreciation rates for our estimates. Given that depreciation rates for intangible capital are high (Corrado et al (2006) report rates as high as $60 \%$ ) the initialization assumption is innocuous. The contribution of an investment to the stock of the asset is only $25 \%$ after two half-lives so investments made prior to 1990 have little effect on the capital stock levels in the late $90 \mathrm{~s}$. A depreciation rate of $20 \%$ implies a half-life of less than 3.5 years while a rate of $30 \%$ reduces the half-life of the investment to 2.3 years. We report our estimates in Table 8 for the depreciation rates used by Corrado et al (2006). Capital stock levels for alternate depreciation rates are shown in Tables A1 and A2 in the Appendix.

\section{Table 8}

\section{India 2008}

Estimate of Intangible Capital Stock using investment data

Billions of INR

\section{Intangible Capital Stock}

Computerized Information

Innovative Property

R\&D (Scientific)

Royalties, Technical Knowledge

Economic Competencies

Brand equity

Firm-specific resources
Percentage of GDP

1295

$3.66 \%$

$0.89 \%$

$2.77 \%$

545

It is comforting to note that the estimates that we get from the Corrado et al (2006) measures are similar to those using investment data and their depreciation rates. One advantage of using investment flows is that it explicitly allows us to vary the depreciation rate and examine its effect on the capital stock. In Figure 2 we show the evolution of the stock of brand equity (advertising and marketing) and innovative property. We also observe that while intangible capital associated with advertising and marketing has stabilized as a fraction of GDP, innovative property capital is still increasing. This leads us to conclude 
that Indian equity valuations relative to GDP will continue to rise as the stock of intangible capital approaches its steady state value.

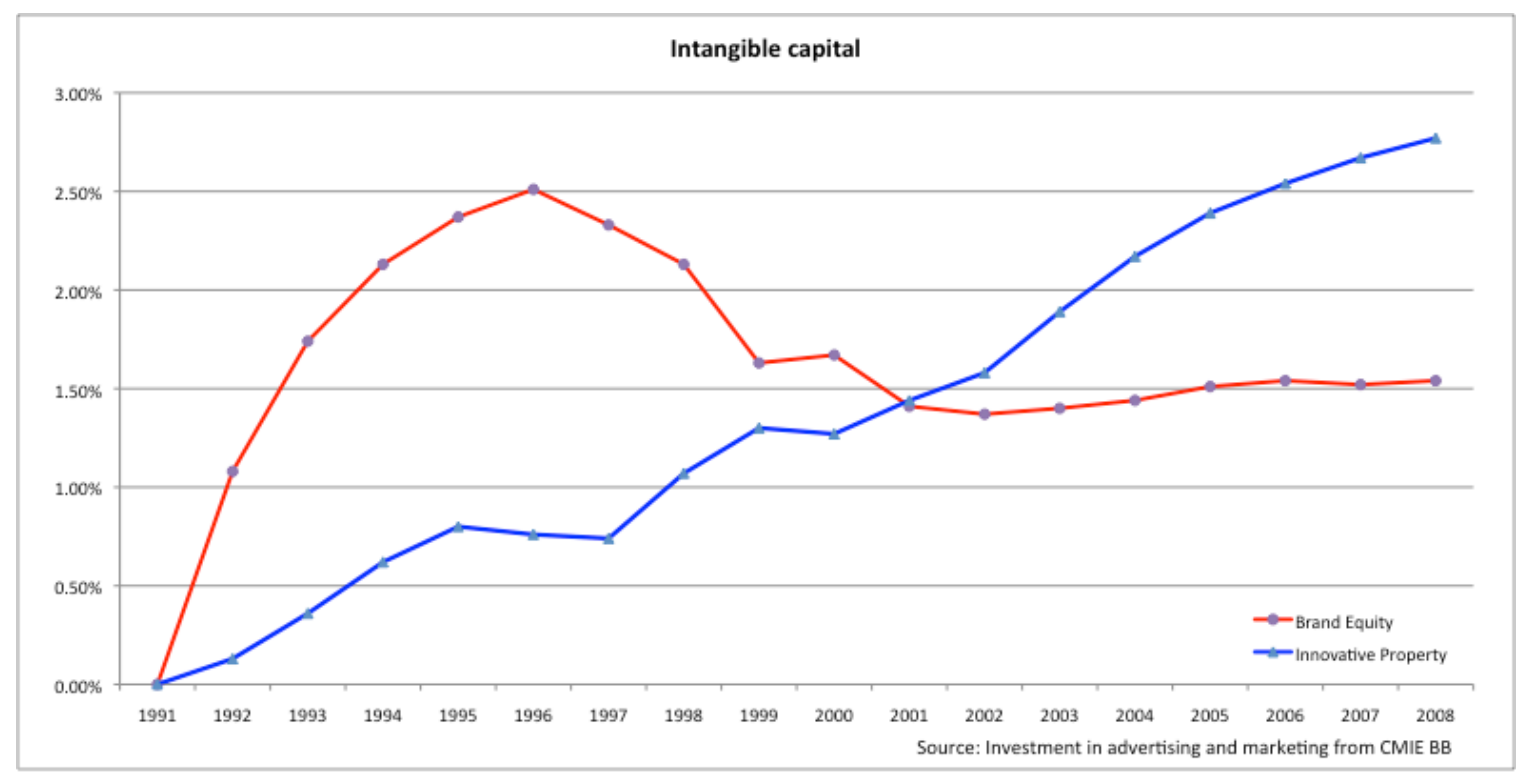

Figure 2

Finally, we use the estimates in Tables 7 and 8 to construct estimates of the entire intangible capital stock in India. We report this in table 9 . In constructing Table 9, we have assumed that investments in firm specific resources in India mimic those in the U.S. Although we do not have investment data for this category we feel that investment in human and organizational capital is likely to be similar in India especially for large firms. In addition, we use the estimates of intangible capital from the Indian National Accounts for the category Computerized Information. 


\section{Table 9}

Estimate of Intangible Capital Stock (India 2008)

\begin{tabular}{|ccccc|} 
& \multicolumn{3}{l}{ Following Corrado et al (2006) } & Using Investment Data \\
\cline { 2 - 4 } & \multicolumn{3}{l|}{} \\
\cline { 2 - 4 }$\quad$ Intangible Capital Stock & 5724 & $16.17 \%$ & \%s. (billion) & \% GDP \\
Computerized Information & 296 & $0.84 \%$ & 5,947 & $16.81 \%$ \\
Innovative Property & 1463 & $4.13 \%$ & 1,295 & $0.84 \%$ \\
R\&D (Scientific) & 394 & $1.11 \%$ & 315 & $3.66 \%$ \\
Royalties, Technical Knowledge & 1069 & $3.02 \%$ & 980 & $2.89 \%$ \\
Economic Competencies & 3893 & $11.00 \%$ & 3,988 & $11.27 \%$ \\
Brand equity & 450 & $1.27 \%$ & 545 & $1.54 \%$ \\
Firm-specific resources & 3443 & $9.73 \%$ & 3,443 & $9.73 \%$ \\
Other intangibles (from accountants) & 368 & $1.04 \%$ & 368 & $1.04 \%$
\end{tabular}

While these estimates for the intangible capital stock are similar to each other, they are lower than the estimates that we obtain using the McGrattan Prescott methodology. One reason is the high depreciation rates used by Corrado et al (2006) another possibility is that organizational capital, in particular investment in learning by doing, is probably underestimated in their analysis ${ }^{20}$.

\section{Equilibrium Equity Values}

In this Section, we use the theoretical framework developed earlier and our estimates of intangible capital to compute equilibrium values for corporate securities in India and compare these to observed values. We begin by documenting the average observed values for both debt and equity in Table 10 and predicted fundamental values in Table 11.

\footnotetext{
20 The reader is referred to McGrattan and Prescott (2005) and the commentary by Edward Prescott at the end of the chapter by Corrado et al (2005) for a discussion on organization capital.
} 
Table 10

Average Observed Corporate Values for India

\begin{tabular}{lcc}
\hline & $1991-2004$ & $2005-2008$ \\
\hline Corporate equities & 0.452 & 1.200 \\
Net corporate debt & 0.335 & 0.268 \\
& & \\
Total relative to NAGDP & 0.787 & 1.468 \\
Total relative to earnings & 17.378 & 18.272 \\
\hline
\end{tabular}

Table 11

Predicted Fundamental Corporate Values for India

\begin{tabular}{|c|c|c|}
\hline & $1991-2004$ & $2005-2008$ \\
\hline \multicolumn{3}{|l|}{ McGrattan-Prescott } \\
\hline Contribution of Domestic tangible capital ${ }^{21}$ & 0.701 & 0.821 \\
\hline Contribution of Domestic intangible capital ${ }^{22}$ & 0.362 & 0.650 \\
\hline Foreign capital & 0.000 & 0.000 \\
\hline Total relative to NAGDP & 1.063 & 1.471 \\
\hline \multicolumn{3}{|l|}{ Corrado et al } \\
\hline Domestic tangible capital & & 0.774 \\
\hline Domestic intangible capital & & 0.152 \\
\hline Foreign capital & & 0.000 \\
\hline Total relative to NAGDP & & 0.926 \\
\hline \multicolumn{3}{|l|}{ Using Investment Data } \\
\hline Domestic tangible capital & & 0.774 \\
\hline Domestic intangible capital & & 0.168 \\
\hline Foreign capital & & 0.000 \\
\hline Total relative to NAGDP & & 0.942 \\
\hline
\end{tabular}

\footnotetext{
$21 k_{m}\left(1-\tau_{d}\right)$

$22 k_{u}\left(1-\tau_{c}\right)\left(1-\tau_{d}\right)$
} 
Although we have abstracted from debt in deriving our valuation relationship (equation 6) the empirical counterpart of claims to the corporate capital stock is the market value of the corporate sector, which includes both equity and net debt. The total market value of the corporate sector is plotted in Figure 3.

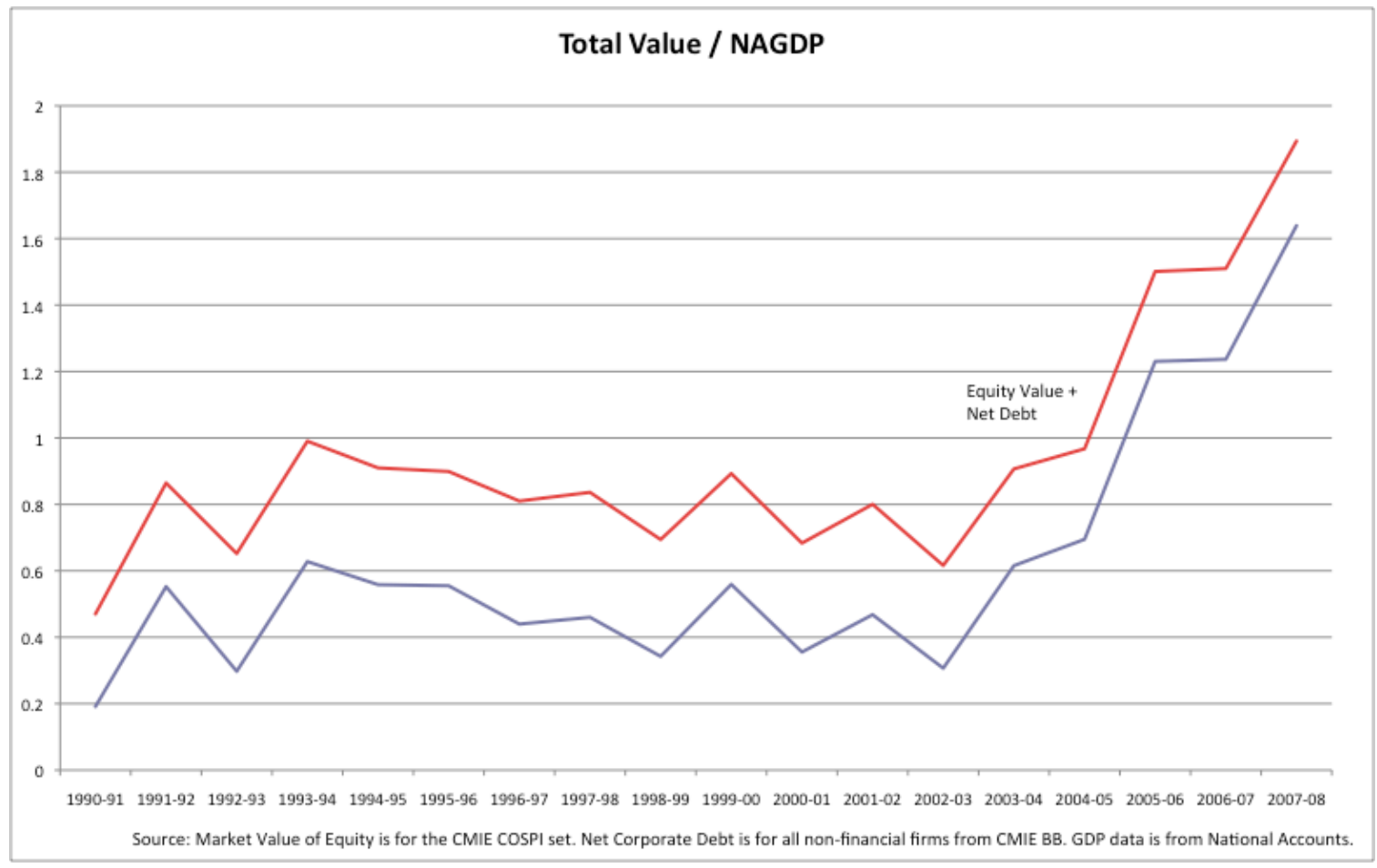

Figure 3

The top line plots market value of equity and net debt as a multiple of NAGDP. The bottom line plots market value of equity as a multiple of NAGDP.

We observe that for the 1991-2004 period the ratio of total corporate value to NAGDP has been relatively constant with a mean value of 0.787 . The predicted equilibrium value for the same time period is 1.09 (Table 11). If we use our model as a benchmark then the conclusion is that, the Indian market was not overvalued over most of the 1991-2004 period - certainly not on average. In fact, 
tangible assets alone account for over $95 \%$ of the value ${ }^{23}$ of the entire market - a point reinforced by Figure 4, which plots corporate capital as a multiple of NAGDP.

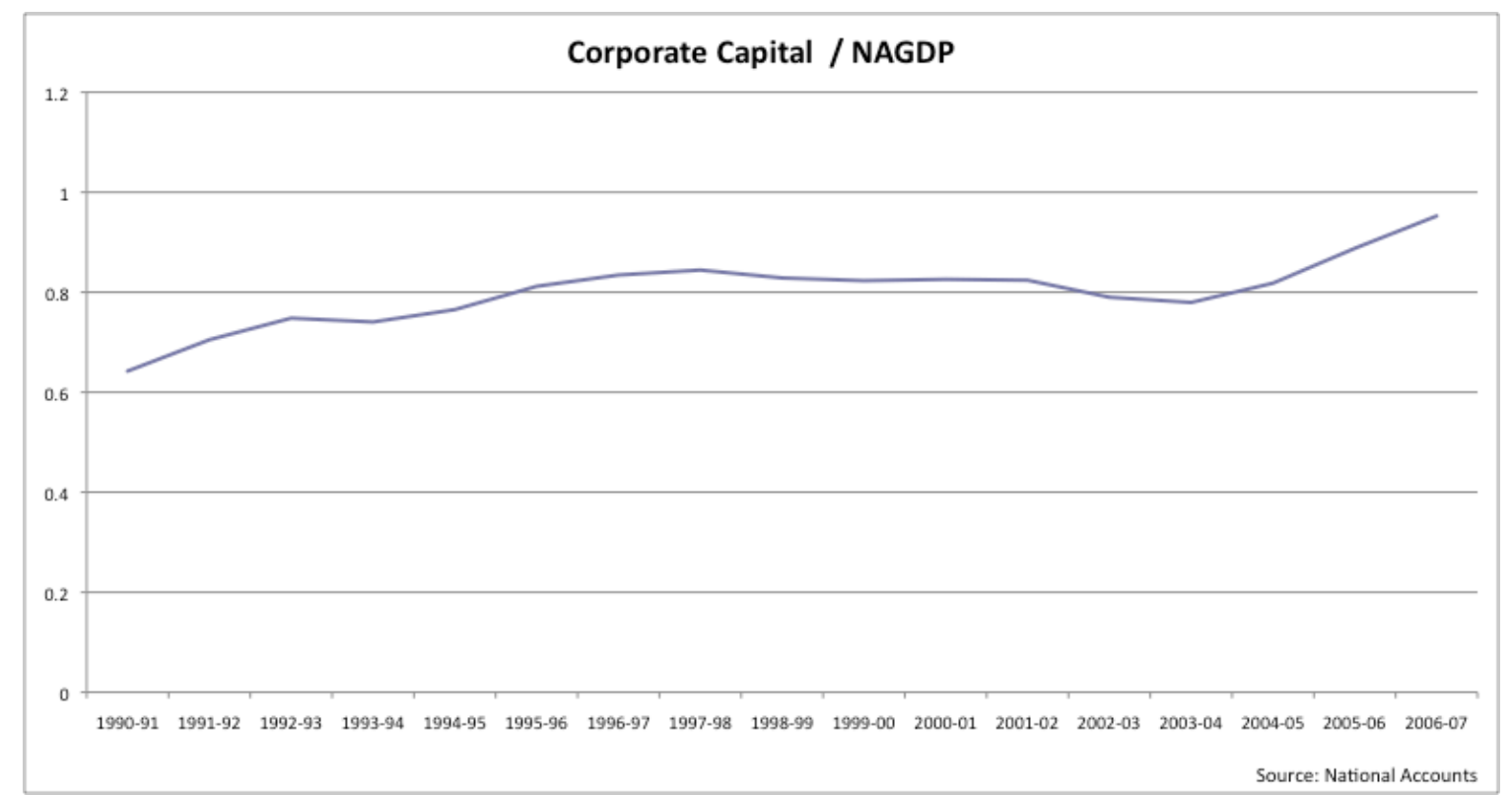

Figure 4

The Indian experience during 1991-2004, where both capital output and corporate valuations relative to GDP were constant presents a contrast to the U.S, where a major puzzle is that while the capital output ratio is fairly constant, corporate valuations relative to GDP have moved considerably. McGrattan and Prescott (2005) attribute this to changes in the tax and regulatory framework.

Next, we examine the 2005-2008 period. One explanation for the run up in equity values relative to GDP is that there was a change in the capital structure

23 The effective distribution tax rate over this period was $4.9 \%$. Note that from equation 6 the contribution of tangible capital stock to corporate valuation is $k_{m}\left(1-\tau_{d}\right)$. 
of firms. If there were debt equity swaps $^{24}$, equity values relative to GDP would increase. To see if this was the case in India we examine the net corporate debt relative to GDP and the debt equity ratio (Figure 5).

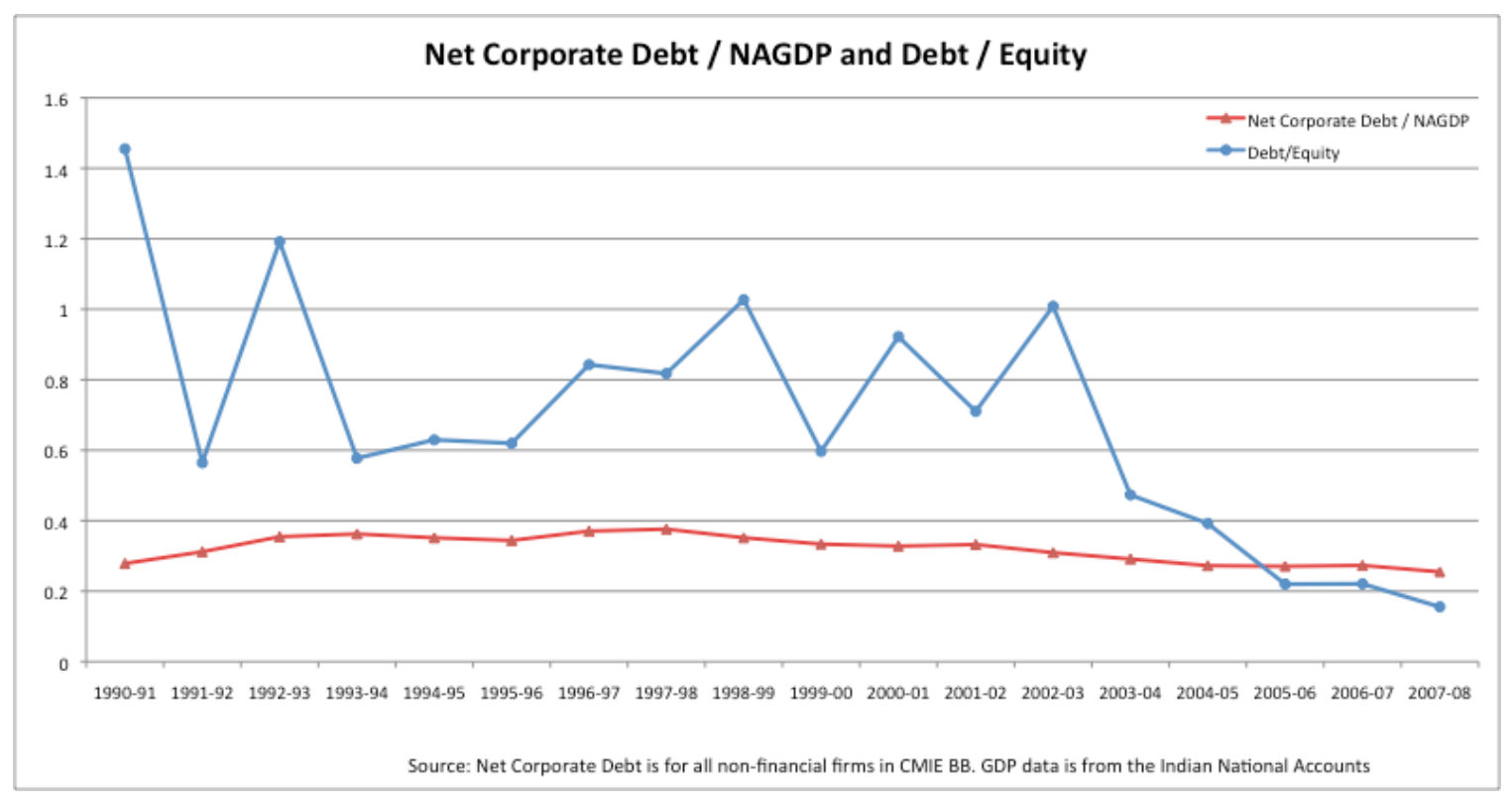

Figure 5

24 With corporations buying back debt and issuing equity or changing the debt equity mix in financing new investments. 
Looking at Figure 5, we see a gradual decline in debt financing starting in 1998 but nothing significant in the 2005-08 period. Hence, this is an unlikely explanation for the precipitous decline in the debt equity ratio in Figure 5, which seems to be the result of an increase in equity valuation.

Is this increase in corporate valuations consistent with changes in the underlying corporate capital stock? The average observed value over this period was 1.468 , which is almost exactly equal to our high estimate of 1.471 but over $50 \%$ more than the low estimate for the fundamental value. That market valuations should increase is apparent from Figure 4. We should have expected a $20-25 \%$ increase in valuations, based solely on the increase in tangible capital. This increase in the tangible capital stock is consistent in the increase in gross private investment over this period. This rate, which averaged $16.51 \%$ during 1991-2004, jumped to 25.5\% during 2005-08. (Figure 6) 


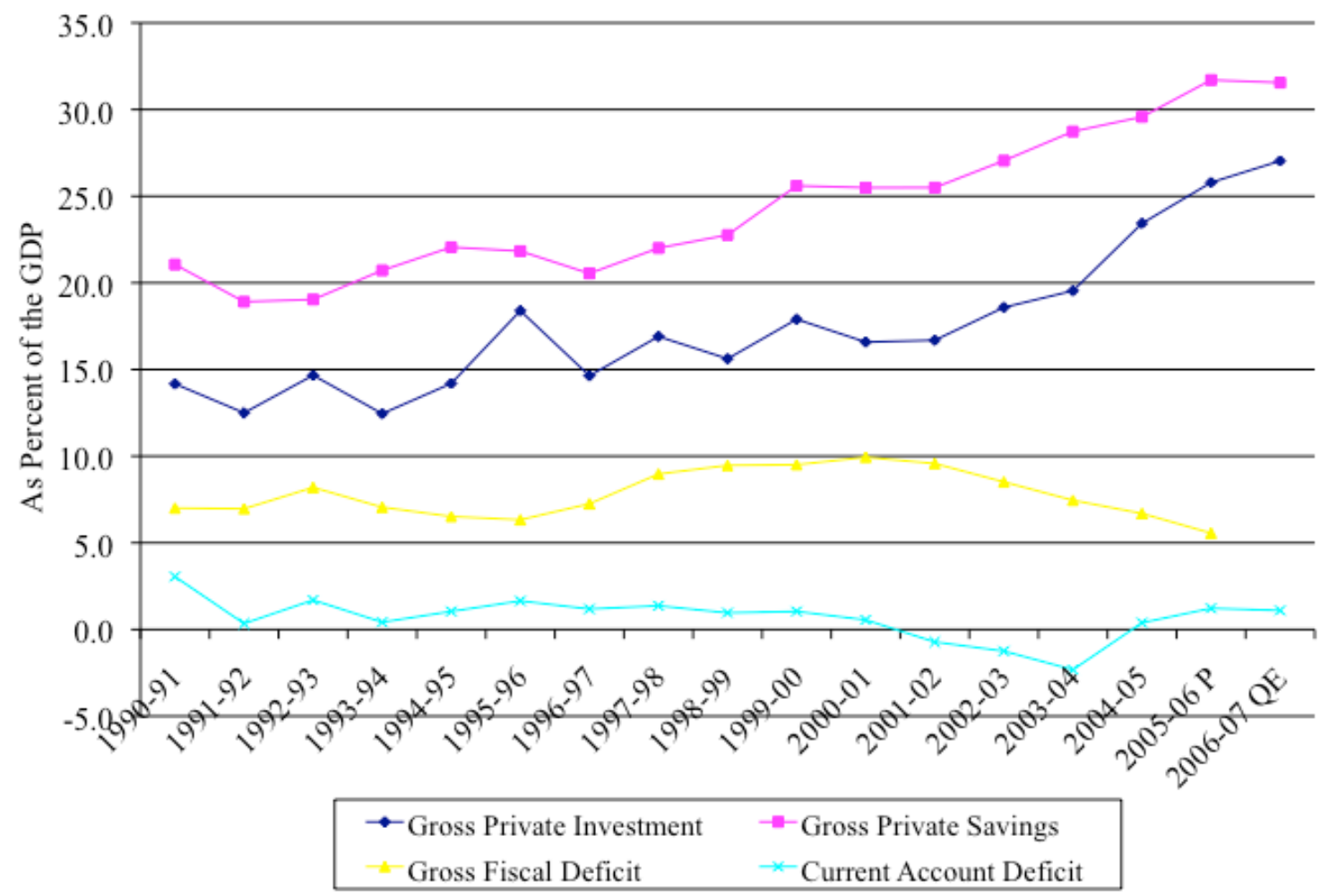

Source: Panagariya (2008)

Figure 6

However, this increase in the savings rate does not imply the valuations observed at the end of 2008. Our analysis suggests that an optimistic estimate of fundamental value of the current Indian equity market is about 1.2 (since debt is about 0.25 ). This is considerably lower than the 1.6 value observed in 2008 . One effect that we have not accounted for is the demand from foreign institutional investors. In 2007, Foreign Institutional Investment was valued at 300 billion dollars (versus a low of 60 billion) and this fact may have important implications in valuing Indian stock markets ${ }^{25}$. If the effect of this demand is to change the marginal investor, the relevant marginal rate of substitution will change, and with it valuations as well. These are issues that we plan to pursue in subsequent research.

25 I thank Surjit Bhalla for this insight. 
In closing, we revisit Figure 2, which suggests that intangible capital in India is still increasing in some sectors. This will lead to a future increase in the equilibrium value of the Indian equity markets relative to GDP. If cross country data is any guide, we expect these markets to stabilize at around 1.5 GDP once intangible capital reaches steady state levels.

\section{Valuation Ratios}

In this section, we relate the price earnings ratio and Tobin's q, to quantities identified in the model developed in Section 2. Both these ratios are widely used as measures of over and undervaluation of equity.

James Tobin introduced $\mathrm{q}$, defined as the ratio of the market value of equity and net debt to tangible capital at replacement cost:

$$
q_{t}=\frac{p_{t}+b_{t}}{k_{m, t+1}}
$$

In the absence of intangible capital, equation 1 implies that the equilibrium value of $q_{t}=1$. Persistent departures from $q_{t}=1^{26}$ are interpreted as an indication of the over or undervaluation of capital markets. Unfortunately, in an economy with changing tax rates and significant intangible capital the usefulness of $q_{t}$ is limited. As was shown in the Section 2, in a setting with corporate taxes, distribution taxes (i.e. taxes on dividends and capital gains) and subsidies to investment (e.g. investment tax credits) the equilibrium relation specifying the price of corporate equity and capital stocks is ${ }^{27}$ :

$$
p_{t}=\left(1-\tau_{d}\right)\left[\left(1-\tau_{s}\right) k_{m, t+1}+\left(1-\tau_{c}\right) k_{u, t+1}\right]
$$

\footnotetext{
26 Some times the historical average value of $\mathrm{q}$ is used as an ad hoc benchmark instead of $\mathrm{q}=1$. See Smithers and Wright (2000)

${ }^{27}$ We remind the reader that in deriving equation 5 we have abstracted from net corporate debt. Empirically this is a small relative to equity.
} 
In this general setting if we define $q_{t}=\frac{p_{t}}{k_{m, t+1}}$ it is readily seen that not only is its equilibrium value not 1 but that it will change with changes in the tax code. In particular, it will change with changes in the tax rates on corporate distributions (dividends and buybacks) and these rates have varied considerably in India from year to year. Thus $q_{t}$ may differ from 1 either because of over or undervaluation in capital markets or simply as a result of changes in the tax rates - the ratio per se does not distinguish between the two effects. For the time period 1991-2008 $q_{t}$ is plotted in Figure 7.

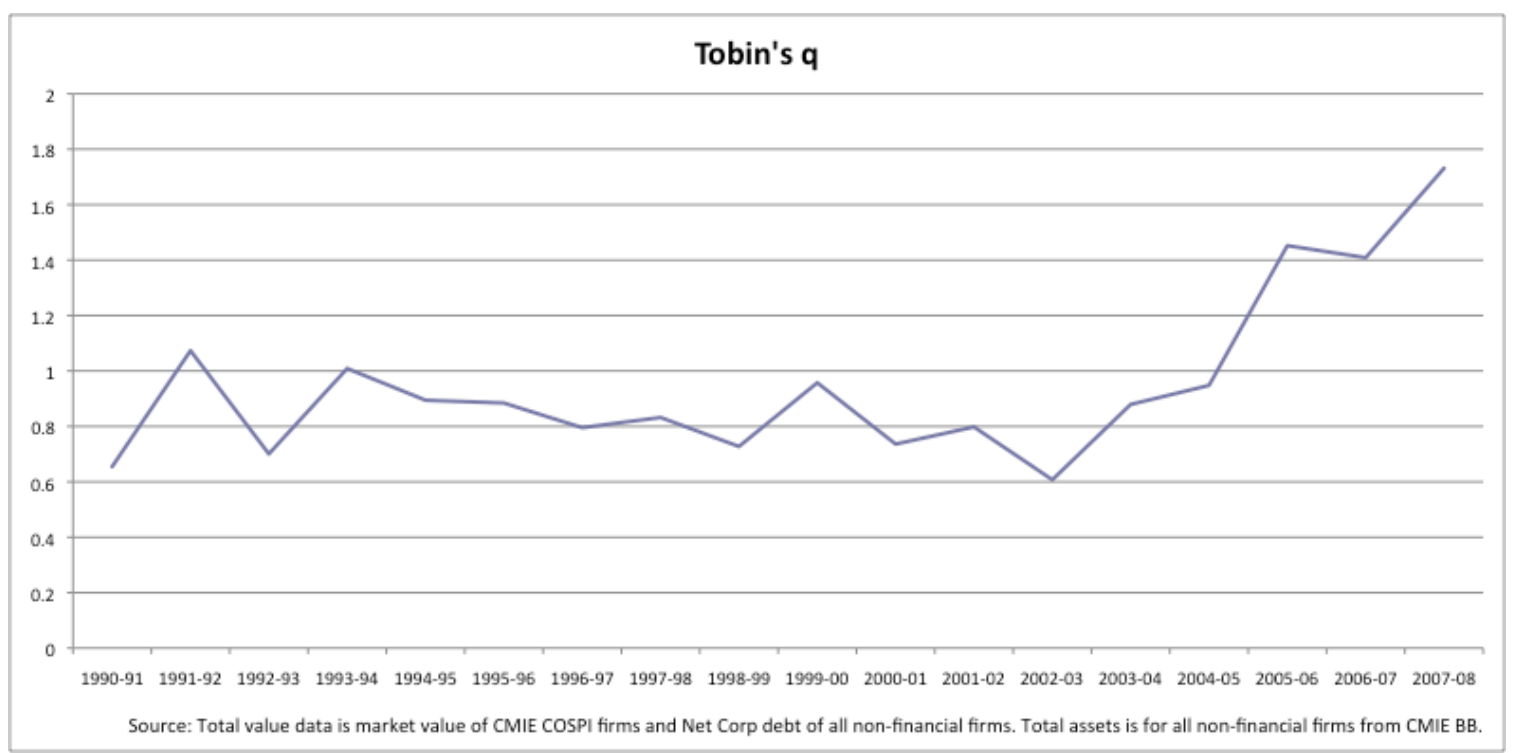

Figure 7

To eliminate the variations in $q_{t}$ due to changes in distribution taxes one can define a tax adjusted $q_{t}^{\tau}$ as

$$
q_{t}^{\tau}=\frac{p_{t}}{\left(1-\tau_{d}\right) k_{m, t+1}}
$$

The advantage of this measure is that it abstracts from the high frequency variation in dividend taxation characteristic of India. If corporate tax rates and 
investment tax rates are relatively stable, then the historical average value of $q_{t}^{\tau}$ provides a benchmark for relative valuation. $q_{t}^{\tau}$ is plotted in Figure 8 . In the presence of intangible capital and changing tax rates, it is apparent that changes in $q_{t}^{\tau}$ do not necessarily represent periods of over or undervaluation of equity markets.

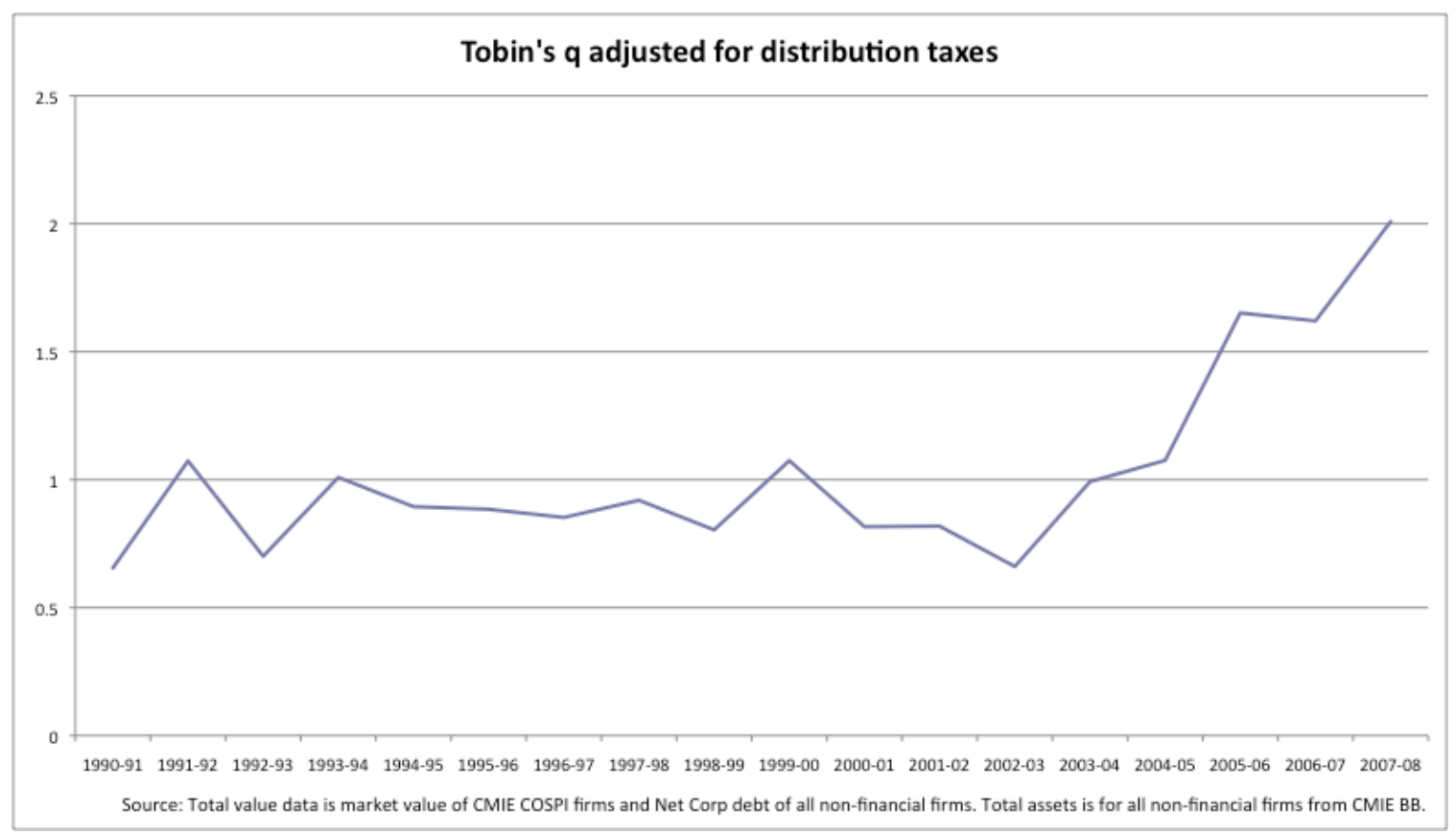

Figure 8

With these caveats in mind, we examine the behavior of $q_{t}^{\tau}$. From 1991 to 2004, the value was fairly constant with a mean of 0.88 . In the absence of intangible capital, theory predicts that this value should be $\left(1-\tau_{s}\right)$. Since $\tau_{s}$ was negligible in India over this period, the average estimated value is slightly below the equilibrium value, leading one to conclude that over the period 1991-2004 the Indian equity market was not overvalued. Starting in 2005, q has increased at an average rate of $23 \%$ per year. Since there was no change in $\tau_{s}$, one can only 
conclude that either the amount of intangible capital dramatically increased or that the market was overvalued relative to its fundamentals.

A measure closely related to $\mathrm{q}$ is the price earnings $(\mathrm{P} / \mathrm{E}) \mathrm{ratio}^{28}$. It is the ratio of the stock price to earnings per share or at the aggregate level the value of equity normalized by after tax corporate profits. It is widely used by financial analysts, and in recent years has been popularized by academics ${ }^{29}$. The $\mathrm{P} / \mathrm{E}$ ratio for the Indian equity markets is plotted in Figure 9.

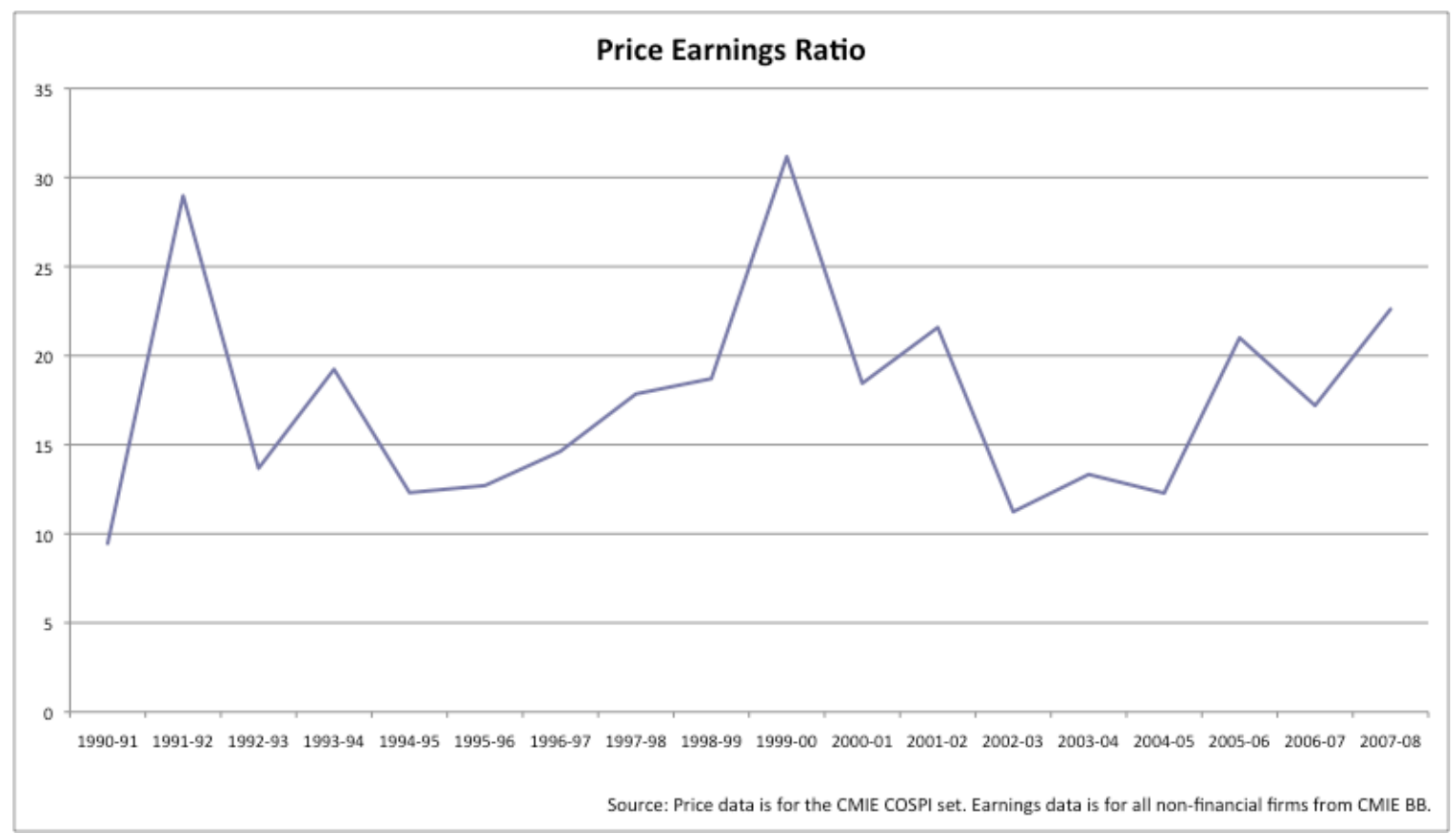

Figure 9

As expected, the P/E has fluctuated considerably over the period 19912008 with a low of 10 , a high of 30 and a mean value of 17.6 . The mean value of the $\mathrm{P} / \mathrm{E}$ ratio in India is about that same as the historical average for the $\mathrm{S} \& \mathrm{P}$

\footnotetext{
${ }^{28}$ In a deterministic world an equilibrium relation is $\mathrm{P} / \mathrm{E}=\mathrm{q} / \mathrm{r}$, where $\mathrm{r}$ is the discount rate. Under uncertainty, variations in $\mathrm{r}$ will make $\mathrm{P} / \mathrm{E}$ more variable than $\mathrm{q}$. The reader is referred to Smithers and Wright (2000) for a detailed comparison of the relative merits of $\mathrm{q}$ and the P/E. 29 See Shiller (2000) and Campbell and Shiller (2001).
} 
500 , which is 18 . Many practitioners consider the market overvalued when the actual value exceeds 24 or 27 (corresponding to a $33 \%$ or $50 \%$ increase over historical norms). Using this criterion, we conclude that except for a brief period in 1999-2000 the India market was fairly priced.

In conclusion, we reiterate that $\mathrm{q}$ and $\mathrm{P} / \mathrm{E}$ ratios, which implicitly abstract from both tax rates and intangible capital, offer inadequate measures of under and over valuation of capital markets. In particular, for economies that exhibit sizable secular growth in intangible capital, as has been observed in India over the last 15-20 years, these metrics offer limited analytical utility.

\section{Concluding Comments}

In this paper, we take a critical look at the relationship between the value of capital stock in the Indian corporate sector and the valuation of claims to this capital stock in capital markets. We address the question of whether Indian equity valuations over the period 1991- 2008 are consistent with three key market fundamentals: corporate capital stock, after tax corporate cash flows and net corporate debt. Our analysis extends the neo-classical growth model to include intangible capital and key features of the tax code and uses national account statistics to estimate the equilibrium value of corporate equity relative to GDP. Our framework can provide policy makers with a benchmark to identify deviations in equity markets relative to those implied by economic fundamentals. In addition, it facilitates a quantitative assessment of policy changes such as, for example, the effect of changes in dividend taxation on stock prices. We caution the reader that although our framework is well suited to examining secular movements in the value of equity relative to GDP, it is not suitable to address high frequency price movements in the stock market. In fact, we know of no 
framework that can satisfactorily account for these movements in terms of the underlying fundamentals. High frequency volatility remains a puzzle.

Based on our analysis, we conclude that in a large measure, Indian equity markets were fairly priced over the 1991-2008 period. 


\section{References}

Abel, Andrew B., N. Gregory Mankiw, Lawrence H. Summers and Richard J. Zeckhauser (1989), "Assessing Dynamic Efficiency: Theory and Evidence," Review of Economic Studies 56,1-20.

Auerbach, Allan J., and Laurence J. Kotlikoff (1987), Dynamic Fiscal Policy (Cambridge University Press).

Bajpai, GN (2004), A Historical Perspective of the Securities Market Reforms http://www.sebi.gov.in/chairmanspeech/histspeech.html

Becker, Gary S \& Barro, Robert J, 1988. "A Reformulation of the Economic Theory of Fertility," The Quarterly Journal of Economics, MIT Press, vol. 103(1), pages 1-25, February.

Bond, Stephen R., and Jason G. Cummins (2000) "The Stock Market and Investment in the New Economy" Brookings Papers on Economic Activity 1, 61125 .

Bosworth, Barry P., (1975) "The Stock Market and the Economy," Brookings Papers on Economic Activity,2, 257-90.

Bosworth, Barry P., Susan M. Collins and Arvind Virmani, (2007), "Sources of Growth in the Indian Economy," India Policy Forum 2006/07,3,1-50.

Brock, William A. (1979), "An Integration of Stochastic Growth Theory and the Theory of Finance, Part 1: The Growth Model," in J. Green and J. Scheinkman (eds.), General Equilibrium, Growth 85 Trade (Academic Press, New York).

Brock, W.A., 1982, "Asset Prices in a Production Economy," in: JJ. McCall, ed., The Economics of Information and Uncertainty (University of Chicago Press, Chicago, IL).

Campbell, John, Y. and Robert J. Shiller, (2001) "Valuation Ratios and the Long Run Stock Market Outlook," Journal of Portfolio Management, 24 (2). 11-26.

Corrado, C., Hulten, C. R. and Sichel, D. E. (2005), "Measuring Capital and Technology: An Expanded Framework", in C. Corrado, J. Haltiwanger and D. 
Sichel (eds.) Measuring Capital in the New Economy (University of Chicago Press).

Corrado Carol A., Charles R. Hulten and Daniel E. Sichel, (2006).

"Intangible Capital and Economic Growth," NBER Working Papers 11948, National Bureau of Economic Research, Inc.

Cox, John C., Jonathan E. Ingersoll, and Stephen A. Ross (1985), "A Theory of the Term Structure of Interest Rates," Econometrica 53, 385-407.

Danthine, Jean-Pierre, John B. Donaldson and Paolo Siconolfi (2008) “ Distribution Risk and Equity Returns" in Rajnish Mehra, Editor, Handbook of the Equity Premium Puzzle (Elsevier)

Donaldson, John B., and Rajnish Mehra (1984), "Comparative Dynamics of an Equilibrium Intertemporal Asset Pricing Model," Review of Economic Studies 51, 491-508.

Fama, Eugene F. and Merton H. Miller (1972), The Theory of Finance, (Holt, Rinehart and Winston).

Grossman, Sanford J., and Robert J. Shiller (1981), "The Determinants of the Variability of Stock Market Prices," American Economic Review 71 (May), 22227.

Hall, Bronwyn H and Robert E. Hall (2000), "The Value and Performance of U.S. Corporations" Brookings Papers on Economic Activity 1993:1, 1-47

Hall, R. E. (2001), "The Stock Market and Capital Accumulation", American Economic Review, 91, 1185-1202.

Kiley, Michael T. (2004) "Stock Prices and Fundamentals: a Macroeconomic Perspective," Journal of Business, 77, 909-936.

Kongsamut, P., S. Rebelo, and D. Xie (2001)."Beyond Balanced Growth," Review of Economic Studies, 68, 869-882

Kydland, Finn, and Edward Prescott (1982), "Time to Build and Aggregate Fluctuations," Econometrica 50, 1345-1371. 
LeRoy, Stephen F., and Richard D. Porter (1981), "The Present-Value Relation: Tests Based on Implied Variance Bounds," Econometrica 49, 555-74.

Lucas, Robert E. (1988), "On the Mechanics of Economic Development," Journal of Monetary Economics 22, 3-42.

Mankiw, N. Gregory, and Stephen P. Zeldes. (1991) "The Consumption of Stockholders and Nonstockholders." Journal of Financial Economics 29, 97-112.

McGrattan, E. R. and Prescott, E. C. (2001), "Taxes, Regulations, and Asset Prices" (Working Paper 610, Federal Reserve Bank of Minneapolis).

McGrattan, E.R. and Prescott, E. C. (2005), "Taxes, Regulations, and the Value of U.S. and U.K. Corporations", Review of Economic Studies, 72, 767-796

Merton, Robert C. (1971), "Optimum Consumption and Portfolio Rules in a Continuous Time Model," Journal of Economic Theory 3, 373-413.

Panagariya, Arvind. (2008). "India: The Emerging Giant." (Oxford University Press).

Prescott, E.C. and R. Mehra, 1980, Recursive Competitive Equilibrium: The Case of Homogeneous Households, Econometrica 48, 1365-1379

Shiller, Robert J. (1981), "Do Stock Prices Move too Much to be Justified by Subsequent Changes in Dividends?" American Economic Review 71, 421-36.

Shiller, Robert J. (2000). "Irrational Exuberance." Princeton University Press, Princeton, NJ.

Smithers, Andrew and Stephen Wright (2000)." Valuing Wall Street: Protecting Wealth in Turbulent Markets." (McGraw-Hill). 


\section{Appendix}

Table A1

Capital stock of Innovative Property (GDP)

\begin{tabular}{|l|l|l|l|l|}
\cline { 2 - 5 } \multicolumn{1}{l|}{} & \multicolumn{4}{c|}{ Depreciation rates } \\
\hline & $10 \%$ & $20 \%$ & $30 \%$ & CHS $(20 \%)$ \\
Year & $(6.9$ years $)$ & $(3.5$ years $)$ & $(2.3$ years $)$ & $(3.5$ years $)$ \\
\hline 1991 & $0.00 \%$ & $0.00 \%$ & $0.00 \%$ & $0.00 \%$ \\
1992 & $0.16 \%$ & $0.16 \%$ & $0.16 \%$ & $0.16 \%$ \\
1993 & $0.46 \%$ & $0.45 \%$ & $0.43 \%$ & $0.45 \%$ \\
1994 & $0.86 \%$ & $0.80 \%$ & $0.75 \%$ & $0.80 \%$ \\
1995 & $1.17 \%$ & $1.04 \%$ & $0.94 \%$ & $1.04 \%$ \\
1996 & $1.28 \%$ & $1.09 \%$ & $0.92 \%$ & $1.09 \%$ \\
1997 & $1.43 \%$ & $1.17 \%$ & $0.95 \%$ & $1.17 \%$ \\
1998 & $1.93 \%$ & $1.60 \%$ & $1.35 \%$ & $1.60 \%$ \\
1999 & $2.29 \%$ & $1.86 \%$ & $1.55 \%$ & $1.86 \%$ \\
2000 & $2.45 \%$ & $1.92 \%$ & $1.54 \%$ & $1.92 \%$ \\
2001 & $2.69 \%$ & $2.07 \%$ & $1.64 \%$ & $2.07 \%$ \\
2002 & $2.91 \%$ & $2.20 \%$ & $1.73 \%$ & $2.20 \%$ \\
2003 & $3.32 \%$ & $2.51 \%$ & $2.01 \%$ & $2.51 \%$ \\
2004 & $3.72 \%$ & $2.80 \%$ & $2.24 \%$ & $2.80 \%$ \\
2005 & $4.11 \%$ & $3.09 \%$ & $2.46 \%$ & $3.09 \%$ \\
2006 & $4.44 \%$ & $3.29 \%$ & $2.59 \%$ & $3.29 \%$ \\
2007 & $4.76 \%$ & $3.49 \%$ & $2.74 \%$ & $3.49 \%$ \\
2008 & $5.03 \%$ & $3.65 \%$ & $2.82 \%$ & $3.65 \%$ \\
\hline
\end{tabular}




\section{Table A2}

\section{Capital stock of Brand Equity (GDP)}

\begin{tabular}{|c|c|c|c|c|}
\cline { 2 - 5 } \multicolumn{1}{l|}{} & \multicolumn{3}{c|}{ Depreciation rates } \\
\hline & $10 \%$ & $20 \%$ & $30 \%$ & CHS $(60 \%)$ \\
Year & $(6.9$ years $)$ & $(3.5$ years $)$ & $(2.3$ years $)$ & $(1.2$ years $)$ \\
\hline 1991 & $0.00 \%$ & $0.00 \%$ & $0.00 \%$ & $0.00 \%$ \\
1992 & $1.08 \%$ & $1.08 \%$ & $1.08 \%$ & $1.08 \%$ \\
1993 & $2.25 \%$ & $2.15 \%$ & $2.05 \%$ & $1.74 \%$ \\
1994 & $3.36 \%$ & $3.08 \%$ & $2.81 \%$ & $2.13 \%$ \\
1995 & $4.39 \%$ & $3.87 \%$ & $3.41 \%$ & $2.37 \%$ \\
1996 & $5.30 \%$ & $4.50 \%$ & $3.84 \%$ & $2.51 \%$ \\
1997 & $5.83 \%$ & $4.75 \%$ & $3.90 \%$ & $2.33 \%$ \\
1998 & $6.15 \%$ & $4.80 \%$ & $3.80 \%$ & $2.13 \%$ \\
1999 & $5.99 \%$ & $4.41 \%$ & $3.32 \%$ & $1.63 \%$ \\
2000 & $6.08 \%$ & $4.35 \%$ & $3.22 \%$ & $1.67 \%$ \\
2001 & $5.87 \%$ & $4.02 \%$ & $2.88 \%$ & $1.41 \%$ \\
2002 & $5.76 \%$ & $3.84 \%$ & $2.72 \%$ & $1.37 \%$ \\
2003 & $5.71 \%$ & $3.75 \%$ & $2.66 \%$ & $1.40 \%$ \\
2004 & $5.70 \%$ & $3.70 \%$ & $2.65 \%$ & $1.44 \%$ \\
2005 & $5.75 \%$ & $3.73 \%$ & $2.70 \%$ & $1.51 \%$ \\
2006 & $5.78 \%$ & $3.75 \%$ & $2.73 \%$ & $1.54 \%$ \\
2007 & $5.79 \%$ & $3.74 \%$ & $2.73 \%$ & $1.52 \%$ \\
2008 & $5.83 \%$ & $3.76 \%$ & $2.75 \%$ & $1.54 \%$ \\
\hline
\end{tabular}

